\title{
New pyridone alkaloids JBIR-130, JBIR-131 and JBIR-132 from Isaria sp. NBRC 104353
}

\author{
Takahiro Hosoya ${ }^{1}$, Motoki Takagi ${ }^{1}$ and Kazuo Shin-ya ${ }^{2}$ \\ The Journal of Antibiotics (2013) 66, 235-238; doi:10.1038/ja.2012.106; published online 5 December 2012
}

Keywords: alkaloids; cell arrest; Isaria; pyridone

A wide variety of screening programs for biologically active compounds have been carried out in our laboratory, employing several assays of fungal metabolites. In the course of our screening program for inhibitors of a cancer target, dynactin-associated protein, a new steroidal compound, JBIR-14, was obtained by activity-guided isolation from the culture extract of an entomopathogenic fungus Isaria sp. NBRC 104353. ${ }^{1,2}$ During the process of isolation of JBIR-14, new cytotoxic compounds, JBIR-130 (1), JBIR-131 (2) and JBIR-132 (3), were discovered. The new pyridone alkaloids $\mathbf{1}-\mathbf{3}$ were purified, and their structures were determined. Herein, the isolation, structure elucidation and biological activities of $\mathbf{1}-\mathbf{3}$ are reported.

\section{EXPERIMENTAL PROCEDURE}

\section{General}

Optical rotations were measured by using a SEPA-300 polarimeter (Horiba, Kyoto, Japan). UV and IR spectra were measured by using a DU730 UV/Vis spectrophotometer (Beckman Coulter, Brea, CA, USA) and an FT-720 spectrophotometer (Horiba), respectively. NMR spectra were collected in $\mathrm{CD}_{3} \mathrm{OD}$ or acetone- $d_{6}$ by using an NMR System 600 NBCL spectrometer (Varian, Palo Alto, CA, USA), with the residual solvent peaks referenced to $\delta_{\mathrm{C}}$ 49.1 and $\delta_{\mathrm{H}} 3.31$ p.p.m. for $\mathrm{CD}_{3} \mathrm{OD}$ and $\delta_{\mathrm{C}} 29.9$ and $\delta_{\mathrm{H}} 2.05$ p.p.m. for acetone- $d_{6}$. The optimizations of HMBC and HSQC spectra for appropriate couplings were 8 and $140 \mathrm{~Hz}$, respectively. High-resolution ESI-MS (HRESIMS) data were recorded by using a LCT-Premier XE MS (Waters, Milford, MA, USA). Normal-phase medium pressure liquid chromatography was performed on a Purif-Pack Si-60 column (Shoko Scientific, Yokohama, Japan). Analytical reversed-phase HPLC was performed on a CAPCELLPAC column $(4.6 \mathrm{~mm}$ i.d. $\times 150 \mathrm{~mm}$; SHISEIDO, Tokyo, Japan) coupled with a 2996 photodiode array detector (Waters) and a 3100 mass detector (Waters). Analytical reversed-phase ultra performance liquid chromatography (Waters) was performed using a BEH ODS column $(2.1 \mathrm{~mm}$ i.d. $\times 50 \mathrm{~mm}$; Waters $)$ coupled with an ACQUITY ultra performance liquid chromatography photodiode array e $\lambda$ detector (Waters) and an LCT-Premier XE MS (Waters). Preparative reversed-phase HPLC was performed on a CAPCELLPACK column $(20 \mathrm{~mm}$ i.d. $\times 150 \mathrm{~mm})$ coupled with an L-2455 photodiode array detector (Hitachi High Technologies, Tokyo, Japan).

\section{Fermentation}

Isaria sp. NBRC 104353 (National Institute of Technology and Evaluation, Tokyo, Japan) was cultivated in $50-\mathrm{ml}$ test tubes containing $15 \mathrm{ml}$ of potato dextrose broth (24 $\mathrm{gl}^{-1}$ potato dextrose; BD Biosciences, San Jose, CA, USA). The test tubes were shaken on a reciprocal shaker $\left(320\right.$ r.p.m.) at $27^{\circ} \mathrm{C}$ for 3 days. Aliquots $(1 \mathrm{ml})$ of the culture were transferred to $100 \mathrm{ml}$ Erlenmeyer flasks with a medium consisting of $3 \mathrm{~g}$ oatmeal (Quaker, Chicago, IL, USA) and $10 \mathrm{ml}$ V8 Mix Juice (Campbell Soup Company, Camden, NJ, USA) and statically incubated at $27^{\circ} \mathrm{C}$ for 14 days.

\section{Isolation}

The culture (20 flasks) was extracted with $80 \%$ aqueous solution of acetone. After filtration and evaporation of the solvent under reduced pressure, the aqueous concentrate was extracted with ethyl acetate $(100 \mathrm{ml} \times 3)$. The organic layer was dried over $\mathrm{Na}_{2} \mathrm{SO}_{4}$ and then evaporated to dryness. The dried residue $(1.2 \mathrm{~g})$ was purified by silica gel medium pressure liquid chromatography (Purif-Pack Si-60) using a hexane/ethyl acetate gradient solvent system (100:0 to $85: 15)$ and $\mathrm{CHCl}_{3} /$ methanol $(\mathrm{MeOH})$ mixture (100:0, 98:2, 95:5, 90:10, $80: 20,30: 70$ and $0: 100)$. A fraction $\left(200 \mathrm{mg}\right.$ ) eluted with $\mathrm{CHCl}_{3} / \mathrm{MeOH}$ (95:5) was then subjected to preparative reversed-phase HPLC with $80 \%$ aqueous $\mathrm{MeOH}$ containing $0.1 \%$ formic acid (flow rate, $8 \mathrm{ml} \mathrm{min}^{-1}$ ) to give $\mathbf{1}$ (retention time $=19.5 \mathrm{~min}, 2.3 \mathrm{mg}), 2($ retention time $=23.0 \mathrm{~min}, 2.0 \mathrm{mg}$ ) and 3 (retention time $=12.5 \mathrm{~min}, 0.8 \mathrm{mg}$ ).

JBIR-130 (1): yellow amorphous solid; $(\alpha)_{\mathrm{D}}{ }^{25}+11.9($ c $0.10, \mathrm{MeOH})$; UV $(\mathrm{MeOH}) \lambda_{\max }(\log \varepsilon) 387(4.2), 255(4.2) \mathrm{nm}$; IR $(\mathrm{KBr}) v_{\max } 3425,1716,1635$ and $1434 \mathrm{~cm}^{-1}$; ${ }^{1} \mathrm{H}$ NMR $\left(600 \mathrm{MHz}, \mathrm{CD}_{3} \mathrm{OD}\right)$ and ${ }^{13} \mathrm{C} \mathrm{NMR}(150 \mathrm{MHz}$, $\mathrm{CD}_{3} \mathrm{OD}$ ), see Table 1; HRESIMS $\mathrm{m} / \mathrm{z} 402.1921(\mathrm{M}-\mathrm{H})^{-}$(calcd for $\left.\mathrm{C}_{22} \mathrm{H}_{28} \mathrm{NO}_{6}, 402.1917\right)$, see Supplementary Figure $\mathrm{S} 1$.

JBIR-131 (2): yellow amorphous solid; $(\alpha)_{\mathrm{D}}^{25}+36.0($ c 0.10 , MeOH); UV $(\mathrm{MeOH}) \lambda_{\max }(\log \varepsilon) 337(4.2), 277(4.2) \mathrm{nm} ; \mathrm{IR}(\mathrm{KBr}) v_{\max } 3430,1735,1604$ and $1438 \mathrm{~cm}^{-1} ;{ }^{1} \mathrm{H}$ NMR $\left(600 \mathrm{MHz}, \mathrm{CDCl}_{3} / \mathrm{CD}_{3} \mathrm{OD}\right)$ and ${ }^{13} \mathrm{C} \quad \mathrm{NMR}$

${ }^{1}$ Biomedicinal Information Research Center (BIRC), Japan Biological Informatics Consortium (JBIC), 2-4-7 Aomi, Koto-ku, Tokyo, Japan and ²Biomedicinal Information Research Center (BIRC), National Institute of Advanced Industrial Science and Technology (AIST), 2-4-7 Aomi, Koto-ku, Tokyo, Japan

Correspondence: Dr M Takagi, Biomedicinal Information Research Center (BIRC), Japan Biological Informatics Consortium (JBIC), 2-4-7 Aomi, Koto-ku, Tokyo 135-0064, Japan. E-mail: motokitakagi03@gmail.com

or Dr K Shin-ya, Biomedicinal Information Research Centre (BIRC), National Institute of Advanced Industrial Science and Technology (AIST), 2-4-7 Aomi, Koto-ku, Tokyo 135-0064, Japan. 
Table $1{ }^{1} \mathrm{H}(600 \mathrm{MHz})$ and ${ }^{13} \mathrm{C}(150 \mathrm{MHz})$ NMR spectroscopic data for JBIR-130 (1), JBIR-131 (2) and JBIR-132 (3)

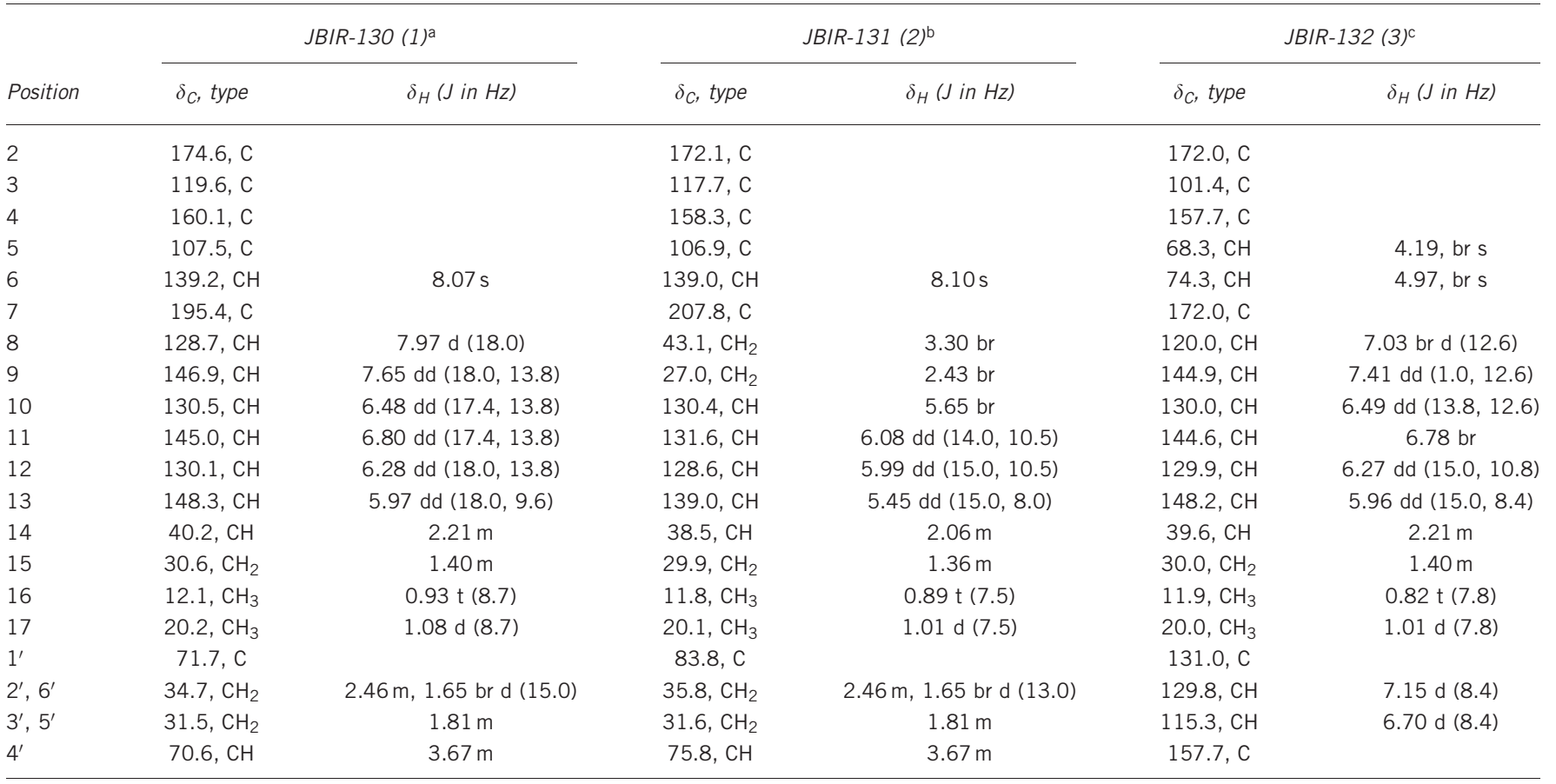

${ }^{\mathrm{a}} \mathrm{CD}_{3} \mathrm{OD}$

${ }^{\mathrm{b}} \mathrm{CD}_{3} \mathrm{OD}-\mathrm{CDCl}_{3}(4: 1)$

${ }^{c}$ Acetone- $\mathrm{d}_{6}$

( $\left.150 \mathrm{MHz}, \mathrm{CDCl}_{3} / \mathrm{CD}_{3} \mathrm{OD}\right)$, see Table 1; HRESIMS $m / z$ 404.2051 $(\mathrm{M}-\mathrm{H})^{-}$ (calcd for $\mathrm{C}_{22} \mathrm{H}_{30} \mathrm{NO}_{6}, 404.2073$ ), see Supplementary Figure S8.

JBIR-132 (3): yellow amorphous solid; $(\alpha)_{\mathrm{D}}{ }^{25}-145.7$ (c 0.10, MeOH); UV $(\mathrm{MeOH}) \lambda_{\max }(\log \varepsilon) 395(4.1), 216(4.2) \mathrm{nm} ; \mathrm{IR}(\mathrm{KBr}) v_{\max } 3430,1710,1662$ and $1459 \mathrm{~cm}^{-1}$; ${ }^{1} \mathrm{H}$ NMR $\left(600 \mathrm{MHz}, \mathrm{CD}_{3} \mathrm{OD}\right)$ and ${ }^{13} \mathrm{C} \mathrm{NMR}(150 \mathrm{MHz}$, $\mathrm{CD}_{3} \mathrm{OD}$ ), see Table 1; HRESIMS $\mathrm{m} / \mathrm{z} 382.1643(\mathrm{M}-\mathrm{H})^{-}$(calcd for $\left.\mathrm{C}_{22} \mathrm{H}_{24} \mathrm{NO}_{5}, 382.1654\right)$, see Supplementary Figure S14.

\section{Cell-growth inhibitory assay}

The human lung carcinoma cell line A549 was used in this study. The cells were cultured in DMEM medium (Wako Pure Chemical Industries, Osaka, Japan) supplemented with $10 \%$ fetal bovine serum (Gibco, Carlsbad, CA, USA), penicillin $\left(100 \mathrm{U} \mathrm{ml}^{-1}\right)$ and streptomycin $\left(100 \mu \mathrm{g} \mathrm{ml}^{-1}\right)$ at $37^{\circ} \mathrm{C}$ in a humidified incubator with $5 \% \mathrm{CO}_{2}$. The cytotoxic activity was estimated using a WST-8 (2-(2-methoxy-4-nitrophenyl)-3-(4-nitrophenyl)-5-(2,4disulfophenyl)- $2 \mathrm{H}$-tetrazolium, monosodium salt) colorimetric assay. A549 cells were incubated in 96-well plates at a density of $1 \times 10^{4}$ cells per well in $100 \mu \mathrm{l}$ of medium overnight, after which they were treated with compounds at various concentrations for $48 \mathrm{~h}$. Next, $10 \mu \mathrm{l}$ of WST-8 reagent solution (Cell Counting Kit; Dojindo, Kumamoto, Japan) was added, and the plate was incubated in a humidified incubator with $5 \% \mathrm{CO}_{2}$ for $1 \mathrm{~h}$ at $37^{\circ} \mathrm{C}$. The absorbance of the formazan dye formed was measured at $450 \mathrm{~nm}$. Actinomycin $\mathrm{D}$ was used as a positive control $\left(\mathrm{IC}_{50}=8.5 \mathrm{nM}\right)$.

\section{Flow cytometry}

A549 cells were exposed to 1 at $5 \mu \mathrm{m}$ for $48 \mathrm{~h}$. The treated cells were collected, washed with phosphate-buffered saline, fixed with cold $70 \%$ ethanol for $2 \mathrm{~h}$ on ice, and then stained with propidium iodide solution $\left(50 \mu \mathrm{g} \mathrm{ml}^{-1}\right.$ of propidium iodide and $10 \mu \mathrm{g} \mathrm{ml}^{-1}$ of RNase A in phosphate-buffered saline) at room temperature in the dark for $30 \mathrm{~min}$. The DNA contents were determined using a flow cytometer (Millipore, Billerica, MA, USA).

Compounds $1-3$ were isolated from the acetone extract of the fungus Isaria sp. NBRC 104353 by medium pressure liquid chromatography and HPLC. The ${ }^{1} \mathrm{H}$ and ${ }^{13} \mathrm{C}$ NMR data for $\mathbf{1}-\mathbf{3}$ (Table 1) suggested that the basic structural skeletons were identical to those of pyridone alkaloids. ${ }^{3-6}$ Detailed structural information was obtained from a series of 2D NMR experiments, including doublequantum filtered-correlation spectroscopy (DQF-COSY), and HSQC and HMBC spectroscopy (Figure 1a, Supplementary Figure S2 - S6, S9 - 13, S15-19).

JBIR-130 (1) was obtained as a yellow amorphous solid, and its molecular formula was determined to be $\mathrm{C}_{22} \mathrm{H}_{29} \mathrm{NO}_{6}$ by HRESIMS. The ${ }^{1} \mathrm{H}$ NMR, ${ }^{13} \mathrm{C}$ NMR and UV absorption spectra were significantly similar to those of militarinones $\mathrm{A}-\mathrm{D},{ }^{3,4}$ which have a 1,4dihydroxy-(5-cyclohexyl)pyridone moiety and a side chain. The sequence from an olefinic methine proton $\mathrm{H}-8\left(\delta_{\mathrm{H}} 7.97\right)$ to methyl protons $\mathrm{H}_{3}-16\left(\delta_{\mathrm{H}} 0.93\right)$ via olefinic methine protons $\mathrm{H}-9\left(\delta_{\mathrm{H}} 7.65\right)$, $\mathrm{H}-10\left(\delta_{\mathrm{H}} 6.48\right), \mathrm{H}-11\left(\delta_{\mathrm{H}} 6.80\right), \mathrm{H}-12\left(\delta_{\mathrm{H}} 6.28\right), \mathrm{H}-13\left(\delta_{\mathrm{H}} 5.97\right)$ and $\mathrm{H}-14\left(\delta_{\mathrm{H}} 2.21\right)$, which was in turn ${ }^{1} \mathrm{H}$ spin-coupled to methyl protons $\mathrm{H}_{3}-17\left(\delta_{\mathrm{H}} 1.08\right)$ and methylene protons $\mathrm{H}_{2}-15\left(\delta_{\mathrm{H}} 1.40\right)$, was established by the DQF-COSY experiment. The E-configuration of the carbon-carbon double bonds at C-8, C-10 and C-12 was confirmed from the vicinal coupling constants of 18.0, 17.4 and $18.0 \mathrm{~Hz}$, respectively, (Table 1 ). ${ }^{1} \mathrm{H}-{ }^{13} \mathrm{C}$ long-range couplings from H-8 and H-9 to ketone carbonyl C-7 $\left(\delta_{\mathrm{C}}\right.$ 195.4) established the structure of the side chain moiety, as shown in Figure 1a.

The low-field resonance at $4-\mathrm{OH}\left(\delta_{\mathrm{H}} 17.25\right)$ in DMSO- $d_{6}$ and the ${ }^{13} \mathrm{C}$ NMR chemical shift at quaternary carbon C-3 ( $\left.\delta_{\mathrm{C}} 119.6\right)$, hydroxy carbon C-4 $\left(\delta_{\mathrm{C}} 160.1\right)$ and C-7 $\left(\delta_{\mathrm{C}} 195.4\right)$ constituted the enol form of a $\beta$-diketone system with strong electron delocalization, and together with $\mathrm{HMBC}$ correlations from $4-\mathrm{OH}$ to aromatic carbons C-3, C-4 and C-5, ${ }^{3}$ implied that the side chain is linked to the pyridone moiety at $\mathrm{C}-3$. The equivalent signal pairs of the methylene protons at $\mathrm{C}-2^{\prime} / \mathrm{C}-6^{\prime}$ and $\mathrm{C}-3^{\prime} / \mathrm{C}-5^{\prime}$ suggested the presence of a 1,4-substituted cyclohexane ring. The HMBC coupling of the olefinic proton $\mathrm{H}-6\left(\delta_{\mathrm{H}} 8.07\right)$ to $\mathrm{C}-1^{\prime}\left(\delta_{\mathrm{C}} 71.7\right)$ and of methylene 
a

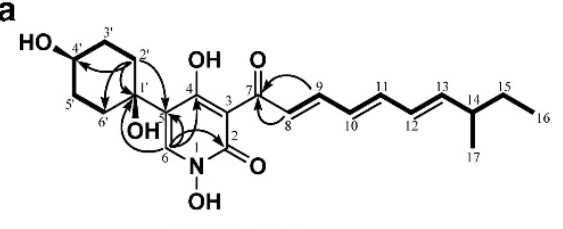

JBIR-130 (1)

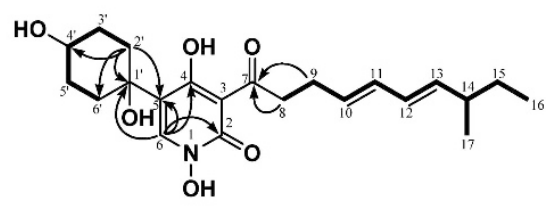

JBIR-131 (2)
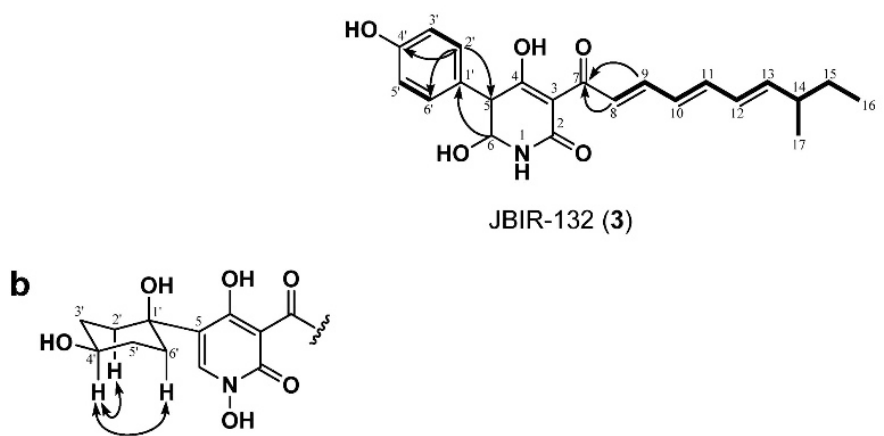

Figure 1 (a) Key correlations observed in $2 \mathrm{D}$ NMR spectra of $1-3$. The bold lines show ${ }^{1} \mathrm{H}-{ }^{1} \mathrm{H}$ DQF-COSY correlations, and the arrows show HMBC couplings. (b) Key NOESY correlations of 1 .

protons $\mathrm{H}-2^{\prime} / \mathrm{H}-6^{\prime}\left(\delta_{\mathrm{H}} 1.65 / 2.46\right)$ to aromatic carbon C-5 suggested that the 1,4-substituted cyclohexane ring is linked to the $\mathrm{C}-5$ position of the pyridone moiety. Analysis of ${ }^{13} \mathrm{C}$ NMR chemical shifts of the pyridone moiety and HRESIMS data revealed the presence of an $\mathrm{N}$-hydroxy-pyridone moiety, which was also reported for fungal metabolites such as militarinone $\mathrm{A}^{3}{ }^{3}$ torrubielonoe ${ }^{5}$ and farinosone $\mathrm{B}^{6}$ The relative configuration of the cyclohexyl moiety could be assigned on the basis of NOESY data (Figure 1b, Supplementary Figure S7). The NOESY correlations between methine proton $\mathrm{H}-4^{\prime}\left(\delta_{\mathrm{H}} 3.67\right)$ and methylene protons Hax-2'/Hax-6 $6^{\prime}\left(\delta_{\mathrm{H}} 2.46\right)$ indicated that the ring was in chair conformation, with the $4^{\prime}-\mathrm{OH}$ adopting an equatorial orientation. The bulky pyridone moiety at $\mathrm{C}-1^{\prime}$ preferred an equatorial orientation. In addition, these NMR spectral data were consistent with the data for the derivatives, militarinone $\mathrm{A}^{3}$ and torrubiellone $\mathrm{A},{ }^{5}$ which have the pyridone moiety and the $4^{\prime}-\mathrm{OH}$ group in the equatorial orientation. The absolute configuration at methine carbon C-14 was unassigned. Accordingly, 1 was determined as 5-(1,4-dihydroxycyclohexyl)-1,4-dihydroxy-3-((2E,4E,6E)-8methyldeca-2,4,6-trienoyl)pyridin-2( $1 H$ )-one.

JBIR-131 (2) was isolated as a light-yellow amorphous solid, and its molecular formula was determined as $\mathrm{C}_{22} \mathrm{H}_{31} \mathrm{NO}_{6}$ on the basis of the HRESIMS data. Comparison of the ${ }^{1} \mathrm{H}$ NMR and ${ }^{13} \mathrm{C}$ NMR spectral data of 1 and 2 indicated that $\mathbf{2}$ had the same substructure of a 1,4-dihydroxy-(5-cyclohexyl)pyridone moiety and a reduced side chain. A sequence from methylene protons $\mathrm{H}_{2}-8\left(\delta_{\mathrm{H}} 3.30\right)$ through $\mathrm{H}_{2}-9\left(\delta_{\mathrm{H}} 2.43\right)$ to $\mathrm{H}-10\left(\delta_{\mathrm{H}} 5.65\right)$ was observed by DQF-COSY, revealing that the triene moiety in $\mathbf{1}$ was replaced by a diene substructure in 2. Thus, the structure of 2 was identified as 5-(1,4dihydroxycyclohexyl)-1,4-dihydroxy-3-((4E,6E)-8-methyldeca-4,6-dienoyl)pyridin-2(1H)-one.

The molecular formula of JBIR-132 (3) was identified to be $\mathrm{C}_{22} \mathrm{H}_{25} \mathrm{NO}_{5}$ by HRESIMS. The ${ }^{1} \mathrm{H}$ and ${ }^{13} \mathrm{C}$ NMR spectroscopic data of $\mathbf{3}$ were similar to those of $\mathbf{1}$ except for the chemical shift of methine carbons $\mathrm{C}-5\left(\delta_{\mathrm{C}} 68.3\right)$ and $\mathrm{C}-6\left(\delta_{\mathrm{C}} 74.3\right)$ and the presence of a phenol moiety $\left(\mathrm{C}-1^{\prime}-\mathrm{C}-6^{\prime}\right)$. The DQF-COSY correlation between methine
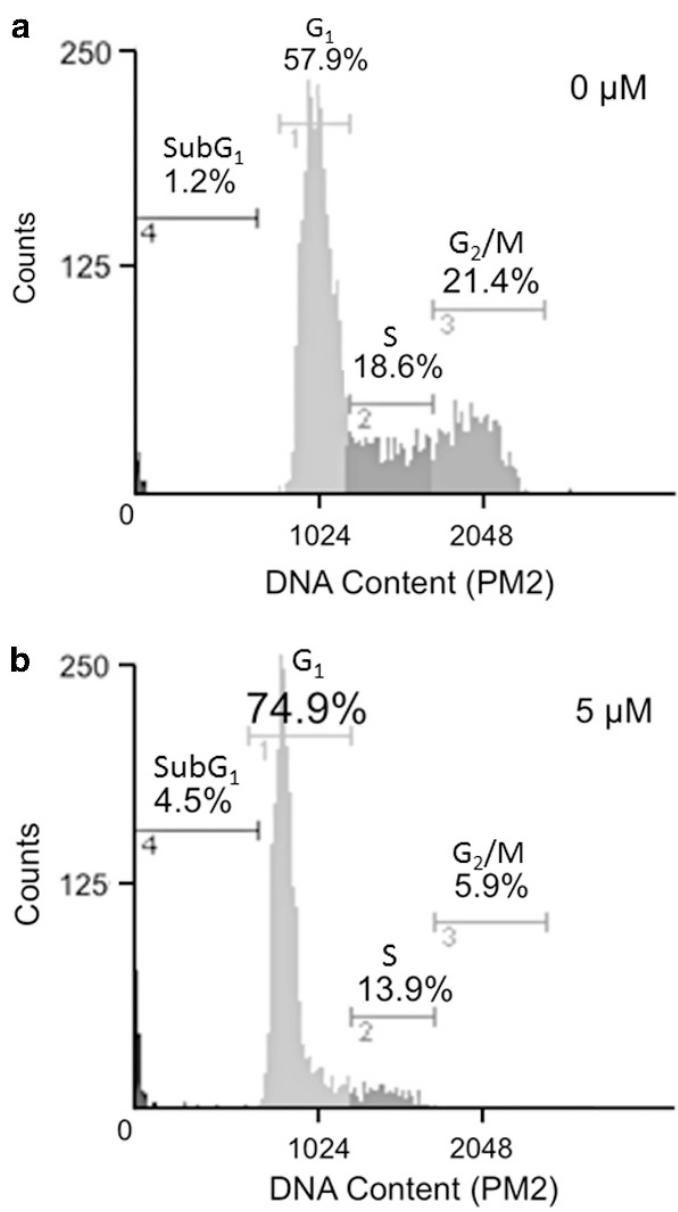

Figure 2 Mode of action of 1 on human lung cancer cell line A549. 
proton $\mathrm{H}-5\left(\delta_{\mathrm{H}} 4.19\right)$ and hydroxy proton $\mathrm{H}-6\left(\delta_{\mathrm{H}} 4.97\right)$ and the HMBC correlation from $\mathrm{H}-6\left(\delta_{\mathrm{H}} 4.97\right)$ to aromatic carbon $\mathrm{C}-1^{\prime}$ $\left(\delta_{\mathrm{C}} 131.0\right)$ suggested that the 4-hydroxyphenyl substituent is attached to $\mathrm{C}-5$ of the pyridone moiety. The relative configuration at $\mathrm{H}-5 / \mathrm{H}-6$ was unclear because of the broad signals. Therefore, 3 was determined as 4,6-dihydroxy-5-(4-hydroxyphenyl)-3-((2E,4E,6E)-8-methyldeca2,4,6-trienoyl)-5,6-dihydropyridin-2(1H)-one.

Pyridone alkaloids with a cis-(1,4-dihydroxy-cyclohexyl) or a 4-hydroxyphenyl moiety and a side chain have been found in secondary metabolites from fungi Paecilomyces sp. ${ }^{3,4,6}$ and Torrubiella sp. ${ }^{5}$ as biologically active compounds. Militarinone $\mathrm{A},{ }^{3}$ which was initially isolated from Paecilomyces militaris, showed neurotrophic effect in PC-12 cells. In addition, militarinone B-D and farinosones $\mathrm{A}-\mathrm{C}^{6}$ have been reported, and militarinone $\mathrm{D}$ has been found to be cytotoxic against PC- 12 cells. ${ }^{4}$ Torrubiellones $\mathrm{A}^{5}$ isolated from Torrubiella sp. exhibited antimalarial activity. Thus, we tested the cell growth-inhibitory activity of $\mathbf{1}-\mathbf{3}$ against human lung carcinoma cells, A549. The $\mathrm{IC}_{50}$ values of $\mathbf{1}-\mathbf{3}$ against A549 cells after $48 \mathrm{~h}$ were 87,53 and $>125 \mu \mathrm{M}$, respectively. To explore the mode of action of 1 , A549 cells were treated with $5 \mu \mathrm{M}$ (which was relatively lower concentration than the $\mathrm{IC}_{50}$ value) of 1 for $48 \mathrm{~h}$, and the cell cycle was examined by flow cytometry. As shown in Figure 2, 1 induced remarkable accumulation of A549 cells in the $G_{1}$ phase; this was concomitant with a decrease in the $S$ and $G_{2} / M$ phase population. The $G_{1}$ arrest was not accompanied by an increase in the sub- $G_{1}$ region of cells with fractional DNA contents, which is typical in the late stages of apoptosis. Thus, $\mathbf{1}$ arrested the cell cycle at the $\mathrm{G}_{1}$ phase without evidence of cytotoxicity. A detailed study of the biological activity of $\mathbf{1}$ is underway.

\section{CONFLICT OF INTEREST}

The authors declare no conflict of interest.

\section{ACKNOWLEDGEMENTS}

This work was supported by a grant from the New Energy and Industrial Technology Department Organization (NEDO).

1 Ueda, J. Y. et al. JBIR-14, a highly oxygenated ergostane, from Isaria sp. NBRC 104353. J. Antibiot. 63, 139-141 (2010).

2 Kunoh, $T$, et al. A novel human dynactin-associated protein, dynAP, promotes activation of Akt, and ergosterol-related compounds induce dynAP-dependent apoptosis of human cancer cells. Mol. Cancer Ther. 9, 2934-2942 (2010).

3 Schmidt, K. et al. Militarinone A, a neurotrophic pyridone alkaloid from Paecilomyces militaris. Org. Lett. 4, 197-199 (2002).

4 Schmidt, K., Rises, U., Li, Z. \& Hamburger, M. Novel tetramic acids and pyridone alkaloids, militarinones $\mathrm{B}, \mathrm{C}$, and $\mathrm{D}$, from the insect pathogenic fungus Paecilomyces militaris. J. Nat. Prod. 66, 378-383 (2003).

5 Isaka, M., Chinthanom, P., Supothina, S., Tobwor, P. \& Hywel-Jones, N. L. Pyridone and tetramic acid alkaloids from the spider pathogenic fungus Torrubiella sp. BCC 2165. J. Nat. Prod. 73, 2057-2060 (2010).

6 Cheng, Y. et al. Farinosones A-C, neurotrophic alkaloidal metabolites from the entomogenous deuteromycete Paecilomyces farinosus. J. Nat. Prod. 67, 1854-1858 (2004)

Supplementary Information accompanies the paper on The Journal of Antibiotics website (http://www.nature.com/ja) 